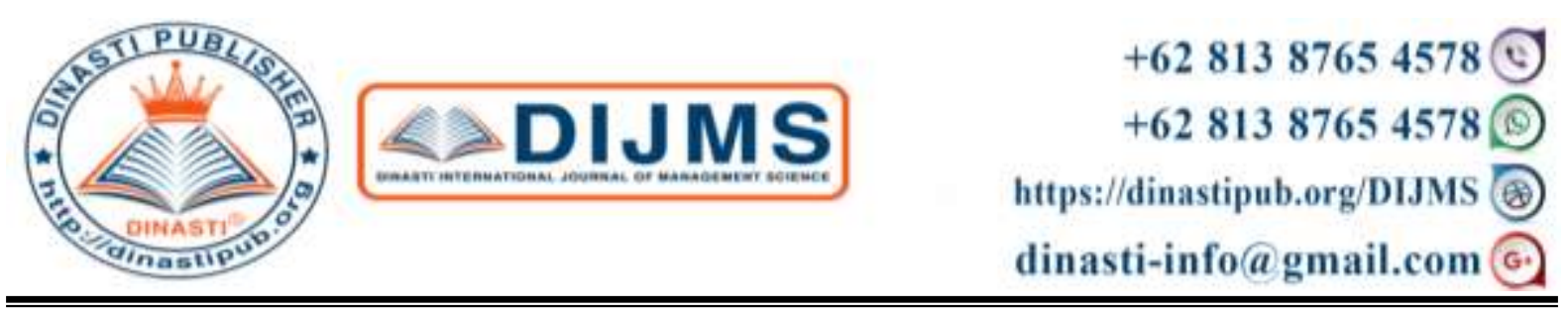

\title{
ANALYSIS OF ORGANIZATIONAL COMMITMENT THROUGH OCB ON EMPLOYEE PERFORMANCE
}

Muhammad Ridwan

Lecturer of Universitas Putra Indonesia YPTK, Padang Indonesia

ARTICLE INFORMATION
Received: 01 March 2020
Revised: 03 March 2020
Issued: 07 March 2020
(filled in by Editor)
Corresponding author: first author
E-mail:
correspondent.author@gmail.com

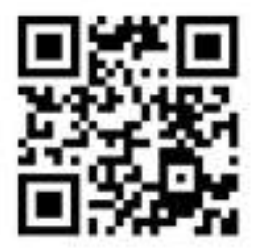

DOI:10.31933/DIJMS

\begin{abstract}
This study aims to analyze the effect of organizational commitment on OCB and employee performance, OCB on employee performance, and analyze the effect of organizational commitment through OCB as an intervening variable on employee performance. The population is all employees who work at SPMI units of Private Universities in West Sumatra, amounting to 241 people. Of the 241 people taken 30 as a sample of validity and reliability so the remaining 211 people still exist. While the number of samples taken using the saturation sampling technique, which is a sampling technique by taking the entire population that is 211 samples. The data collection method uses the survey method, followed by the statistical method to test the hypothesis by path analysis. The results of this study indicate that organizational commitment has a positive and significant effect on OCB and employee performance, so does OCB has a positive and significant effect on employee performance. In addition, organizational commitment through OCB also has an influence on employee performance.
\end{abstract}

Keywords: Organizational Commitment, Organizational Citizenship Behavior, and Employee Performance.

\section{INTRODUCTION}

Educating the life of the nation, is the great ideals of the Indonesian people as set out in the fourth paragraph of the opening of the 1945 Constitution of the Republic of Indonesia. internationally. Today when viewed further human resources in Indonesia have competitiveness that is still quite alarming. Based on data released by The Global Competitiveness Index, the level of competitiveness of the Indonesian people ranks 37th out of 140 Countries assessed in 2015-2016. This sequence is still below Singapore which is ranked 2, Malaysia ranked 18 and Thailand which is ranked 32. Seeing the low 
competitiveness and the Human Resource Development Index gives an indication of problems in the system of education administration, especially higher education, in Indonesia.

Internal Quality Assurance System (SPMI), is a systemic activity of higher education quality assurance by each university autonomously to control and improve the implementation of higher education in a planned and sustainable manner. This SPMI basically aims to guarantee the quality of education organized by public and private tertiary education, namely to guarantee the quality of tertiary education organized by tertiary institutions, through the organization of Higher Education Tridharma. This can be implemented internally by the relevant tertiary institution, controlled and audited through accreditation activities carried out by BAN-PT or other institutions externally. So that the objectivity of the assessment of the maintenance and improvement of academic quality on an ongoing basis in a college can be realized various problems of higher education in Indonesia.

In accordance with the aim of SPMI to guarantee the quality of education, the implementation of SPMI's performance which is in accordance with the setting of the national standard of higher education should be able to be used as a solution for increasing accreditation in each private tertiary institution in West Sumatra. But unfortunately this seems not to be realized, because based on data obtained from the Forlap Dikti in 2017, there are still very few universities in West Sumatra that are accredited A, not even up to $1 \%$. With the provision of education by private tertiary institutions, it is expected that the graduates produced will have the same competencies as state tertiary institutions.

Constraints faced at the Private University in West Sumatra need to be addressed in more depth so that private universities have a lot of BAN-PT accreditation in position A. The lack of acquisition in position A indicates the performance of SPMI employees at each university is still less than the maximum, so it is necessary revamping SPMI employees in order to have better performance.

Based on preliminary research it can be indicated that the lack of optimal performance of SPMI employees at private tertiary institutions in West Sumatra is partly due to the still weak sanctions imposed by university leaders on SPMI employees. As a result there are still many SPMI employees who do not heed their duties and responsibilities as SPMI employees at tertiary institutions.

Employee performance is a series of employee behaviors that contribute, both positively and negatively, to the completion of organizational goals (Colquitt et al, 2011: 35). The achievement of the objectives of a company is only possible because of the efforts of the actors found in the organization of the institution or company. In this case there is actually a close relationship between individual performance with the performance of the institution or company performance. In other words, if employee performance is high, there is a high probability that the company's performance is also high.

Employee performance is influenced by various factors including organizational citizenship behavior (OCB), perceived organizational support (POS), organizational commitment and competence. Robbins and Judge (2012: 40) define OCB as a choice behavior that is not part of an employee's formal work obligations, but supports the effective functioning of the organization. With the high employee OCB, it makes employees feel part 
of the organization so they feel partly responsible for the achievement of organizational goals. The conditions of employees who have high OCB levels make them work with enthusiasm, carry out work according to targets and even exceed so that in the end can improve employee performance.

In addition to OCB, there are other factors that can affect employee performance is organizational commitment. Organizational commitment is a condition where an employee sides with a particular organization and its goals and desires to maintain membership in the organization (Robbins and Judge, 2012).

The realization of a conducive situation when employees and organizations have the same synergy in the orientation of achieving goals, striving to achieve the specified targets is a necessity when an employee sides with the organization. High organizational commitment owned by employees can make employees work with enthusiasm and enthusiasm to realize the achievement of organizational goals. This situation can create organizational citizenship behavior and increase employee performance. This is consistent with research conducted by Allameh et al, (2011), Ortiz et al, (2015), Holsblat (2014), Saxena and Saxena (2015) states that organizational commitment has a significant effect on organizational citizenship behavior and has an impact on performance the employee.

Based on the background description and previous research the authors are interested in conducting research on Organizational Commitment Analysis through Organizational Citizenship Behavior on Employee Performance.

In accordance with the problems raised in the study, the objectives of this study are:

1) Analyze the effect of organizational commitment on OCB.

2) Analyze the effect of organizational commitment on employee performance.

3) Analyzing the influence of OCB on employee performance.

4) Analyze the effect of organizational commitment and OCB simultaneously on employee performance.

5) Analyze the effect of organizational commitment through OCB on employee performance.

\section{LITERATURE REVIEW}

\section{Organizational Commitment}

Organizational commitment is the level to which employees believe and accept the goals of the organization and wish to live together with the organization (Mathis and Jackson, 2011: 122). According to Robbins and Judge, (2012: 100) provides a definition that organizational commitment is a condition in which an employee sides with a particular organization and its goals and desires to maintain membership in the organization. The realization of a conducive situation when employees and organizations have the same synergy in the orientation of achieving goals, striving to achieve the specified targets is a necessity when an employee sides with the organization. Organizational commitment is needed in this regard.

Sopiah (2008) states that organizational commitment is a psychological bond to employees that is characterized by strong trust and acceptance of the goals and values of the 
organization, willingness to work towards the achievement of organizational interests and the desire to maintain a position as a member of the organization. Meanwhile according to Ortiz et al (2015) Organizational commitment is an emotional connection that employees feel with their work.

According to Steer and Porter in Sopiah (2008) suggested that there are a number of factors that influence employee commitment to the organization, namely: 1) Personal factors include job expectation, psychological contracts, job choice factors, and personal characteristics (personality). Because all of these factors will form an initial commitment; 2) Organizational factors, including initial work experience, job scope, supervision, organizational consistency goals. All of these factors will give rise to and form responsibilities; and 3) Non-organizational factors, which include availability of alternative jobs. Factors that do not originate from within the organization, for example the presence or absence of other work alternatives. If there is something better then the employee will leave it.

Robbins (2012) classifies organizational commitment with three separate dimensions, namely:

1. Affective Commitment

Affective commitment is an emotional feeling for an organization and a belief in its values. Someone who has a strong affective commitment will continue to work in an organization because they really want to do that.

2. Continuance Commitment

Sustained commitment is the economic value that is felt from surviving in an organization compared to leaving the organization. An employee may stay and commit to the organization and employer because he is given a high enough reward. This commitment causes an employee to stay in an organization because they need it.

3. Normative Commitment

Normative commitment is a person's obligation to survive in an organization for moral or ethical reasons. This commitment causes an employee to stick to a job because they feel obliged to do it. In other words, this normative commitment is related to feeling obligated to continue working in an organization.

\section{Organizational Citizenship Behavior (OCB)}

Organizational citizenship behavior as behavior exhibited by an employee who is not part of Jex's (2002) job description. Robbins and Judge (2012) define OCB as choice behavior that does not form part of an employee's formal work obligations, but supports the effective functioning of the organization. Shweta and Srirang (2009) state that OCB is characterized by efforts in any form that are carried out based on employee discretion that provides benefits to the organization without expecting anything in return. Kumar et al. (2009) defines OCB as individual behavior that contributes to the creation of organizational effectiveness and is not directly related to the organization's reward system.

OCB is very important to support the effectiveness of organizational functions, especially in the long run. According to Podsakoff et al. (2000), OCB influences 
organizational effectiveness for several reasons: 1) OCB can help improve the productivity of coworkers; 2) OCB can help improve managerial productivity; 3) OCB can help make efficient use of organizational resources for productive purposes; 4) OCB can reduce the level of need for the provision of organizational resources in general for the purposes of maintaining employees; 5) OCB can be used as an effective basis for coordination activities between team members and between work groups; 6) OCB can improve an organization's ability to obtain and maintain reliable human resources; 7) OCB can improve organizational performance stability; 8) OCB can improve an organization's ability to adapt more effectively to changes in its environment.

According to Williams and Anderson in Shweta and Srirang (2010) as for organizational citizenship behavior can be measured through: 1) Altruism, with indicators: helping colleagues, replacing work roles, giving direction; 2) Courtesy with indicators: mutual respect, not making trouble, consultation; 3) Sportsmanship with indicators: time, problems, accepting policies, tolerating circumstances; 4) Conscientiousness with indicators: reporting, work completion, useful work; and 5) Civic Virtue with indicators: care, participation, recommendations.

\section{The Performance}

Performance is the value of a series of worker behaviors that contribute, both positively and negatively, to the completion of organizational goals (Colquitt et al, 2011). Another opinion states that performance is the result of work related to organizational goals such as quality, efficiency and other performance of effectiveness (Gibson, et al, 2012). Rogelberg (2007), has determined the performance of activities that are usually part of the work and activities of individuals and must do so.

According to Sinambela (2016) employee performance is the ability of employees to do certain skills. Employee performance is very necessary, because with this performance will be known how far their ability to carry out the tasks assigned to it. Mangkunegara (2011) performance is the result of quality and quantity of work achieved by an employee in carrying out their duties in accordance with the responsibilities given to him. Wibowo (2016) performance is about doing work and the results achieved from the work. Performance is about what is done and how to do it.

As according to Wirawan (2009), performance can be influenced by several factors, including namely covering:

1. Internal factors of employees, namely factors from within the employee which are inherited factors from birth and factors obtained when he develops. Inherited factors, such as talent, personal nature, and physical and mental condition. Meanwhile, factors obtained, for example such as knowledge, skills, work ethic, work experience, and work motivation.

2. Organizational internal environmental factors. In carrying out their duties, employees need the support of the organization where they work. This support greatly influences the low level of employee performance. Internal organizational factors include robot technology, compensation systems, work climate, organizational strategy, support of 
resources needed to carry out the work, as well as management and compensation systems

3. Organizational external environmental factors. Organizational external environmental factors are circumstances, events, or situations that occur in the organization's external environment, for example an economic crisis.

According to Mangkunegara (2011) states regarding 4 (four) employee performance factors as performance appraisal standards, namely: 1) Quality of work, which includes accuracy, accuracy, skills and cleanliness; 2) Work quantity, including routine and nonroutine or extra output; 3) Reliability, or whether it is reliable, that is, whether or not it can follow instructions, capabilities. initiative, caution and crafts; and 4) Attitudes which include the attitudes of other employees, work and cooperation with the company.

\section{Concetual Framework}

Based on the research objectives and literature review, the analytical framework in this study is presented in the form of Figure 1. Where organizational commitment variables are independent variables, performance variables are dependent variables and OCB variables are intervening variables, or variables that mediate between independent and dependent variables.

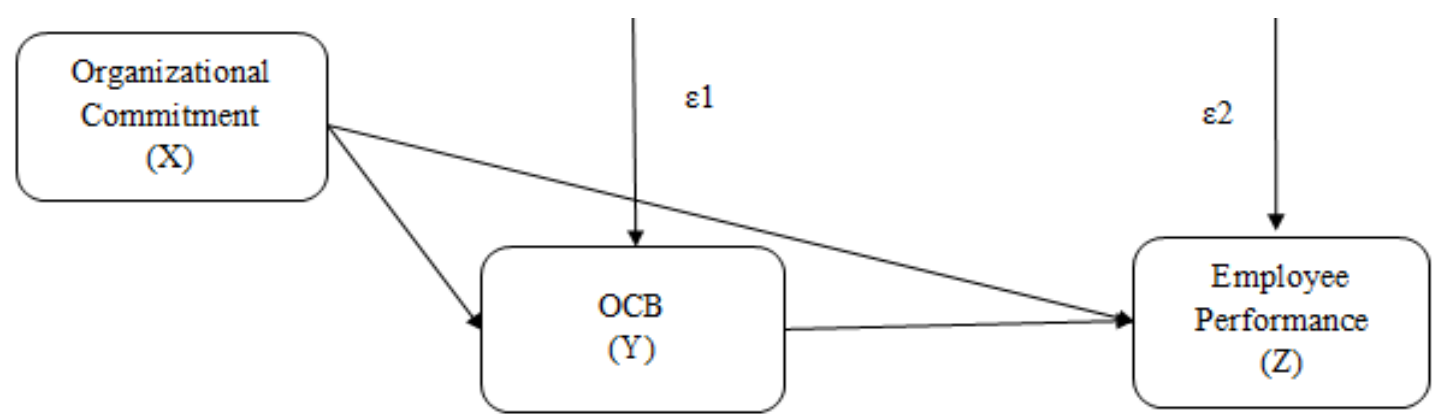

\section{Hypothesis}

Figure 1. Concetual Framework

Based on the problem examined, then a hypothesis is drawn as follows:

$\mathrm{H}_{1} \quad$ : Organizational commitment influences OCB.

$\mathrm{H}_{2}$ : Organizational commitment influences employee performance.

$\mathrm{H}_{3} \quad$ : OCB affects employee performance.

$\mathrm{H}_{4}$ : Organizational commitment and OCB simultaneously influence employee performance.

$\mathrm{H}_{5} \quad$ : Organizational commitment through OCB affects employee performance.

\section{RESEARCH METHODS}

The unit of analysis of this study are employees who work at SPMI units of Private Universities in West Sumatra, amounting to 241 people. Of the 241 people taken 30 as a sample of validity and reliability test so the rest there are still 211 people. While the number of samples taken using the saturation sampling technique, which is a sampling technique by taking the entire population that is 211 samples. 
The research approach used in this study is a quantitative approach using path analysis. This analysis is a development of the regression equation, which is one of the choices in order to study the dependence of a number of variables in the model. This analysis is a good method to explain if there is a large set of data to analyze and look for a causal relationship (Ghozali, 2012). Data analysis tools for SPSS application program version 21.0.

After being analyzed then continued with the determination analysis test (R Square), partial hypothesis testing ( $\mathrm{t}$ test) 5 percent error tolerance, and testing the mediation hypothesis with the Sobel test (Sobel test). But beforehand tested the research instrument (questionnaire) with the validity and reliability test, as well as conducting a normality test.

\section{FINDINGS AND DISCUSSION}

Result

Based on the analysis results it was found that:

1. From the results of the descriptive analysis, an average score (mean) of each statement of organizational commitment variable has a value in the range of 3.40 4.19 , which means the mean value has a high category. This proves that the majority of SPMI employees expect organizational commitment to be implemented properly.

2. From the results of the descriptive analysis conducted, the mean score of each statement of organizational citizenship behavior variable has a value which ranges from 3.40 to 4.19 , which means that the mean value has a high category. This proves that most SPMI employees expect to have better organizational citizenship behavior.

3. From the results of descriptive analysis conducted, the average score (mean) of each statement of employee performance variable has a value in the range from 3.40 to 4.19 , which means the mean value has a high category. This proves that most SPMI employees expect to have better performance.

\section{Path Analisis}

To answer the objectives in this study, the main structure in the research model was broken up into two sub-structures. Where to answer objective 1 with the first sub-structure, to answer objectives 2, 3 and 4 using the second sub-structure, and to answer goal 5 the values taken are the output values of the first and second sub-structures to see direct and indirect effects. The following is the SPSS output of the two structures summarized in the following able.

Table 1.

SPSS Output Two Sub-Structures.

\begin{tabular}{lccccc}
\hline Model & \multicolumn{2}{c}{$\begin{array}{c}\text { Unstandardized } \\
\text { Coefficients }\end{array}$} & $\begin{array}{c}\text { Standardized } \\
\text { Coefficients }\end{array}$ & t & Sig. \\
\cline { 2 - 4 } & $\mathbf{B}$ & Std. Error & Beta & & \\
\hline $\mathrm{X}-\mathrm{Y}$ & 1.066 & 0.057 & 0.792 & 18.759 & 0.000 \\
$\mathrm{X}-\mathrm{Z}$ & 0.487 & 0.068 & 0.423 & 7.176 & 0.000 \\
$\mathrm{Y}-\mathrm{Z}$ & 0.411 & 0.050 & 0.480 & 8.158 & 0.000 \\
\hline
\end{tabular}

Source: Data processed from SPSS output. 
The output results above are entered into the structural equation image as follows:

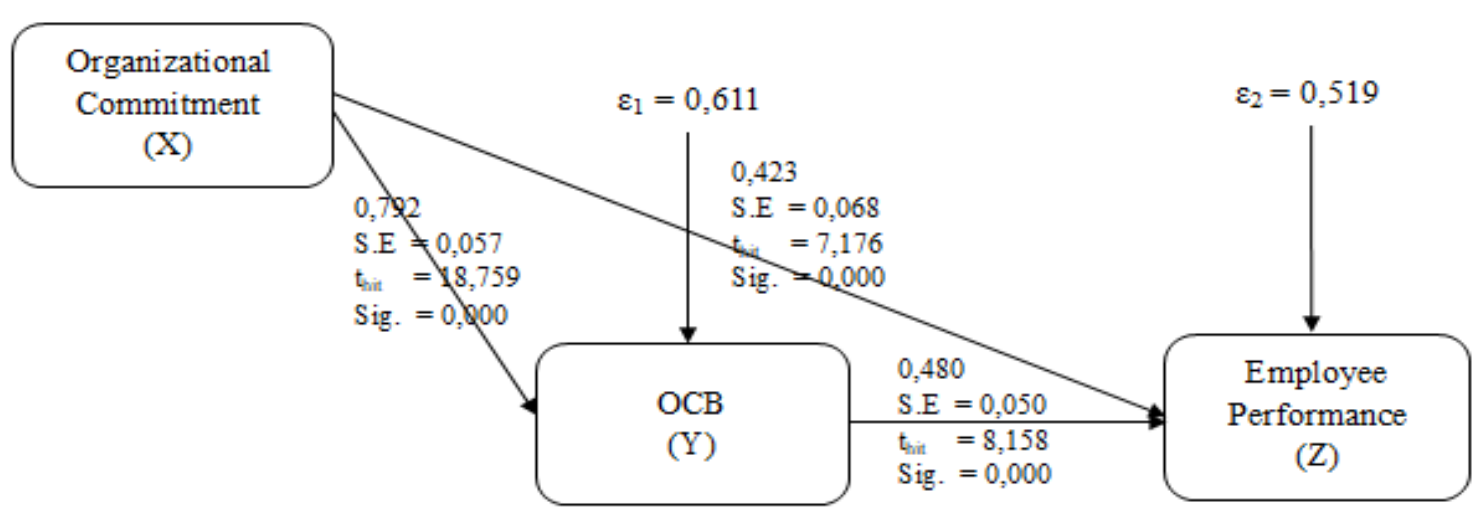

Figure 2. Path Analysis Results

\section{Hypothesis Testing}

1. Effect of Organizational Commitment on OCB.

From the results of the SPSS output as shown in Table 1, the $t$ value of the calculated variable $\mathrm{X}$ to $\mathrm{Y}$ is 18,759 , with a significance level of 0,000 , because the significance level is over $<0.05(0.000<0.05)$, it can be concluded that the organizational commitment influences the OCB. Based on the explanation, $\mathrm{H} 0$ is rejected and $\mathrm{H} 1$ is accepted, meaning that organizational commitment has an effect on OCB.

The results of this study support research conducted by Allameh et al. (2011), Ortiza et al. (2014), Holsblat (2014), Saxena and Saxena (2015) which state that organizational commitment has a significant effect on organizational citizenship behavior.

Organizational commitment is a condition where an employee sides with a particular organization and its goals and desires to maintain membership in the organization (Robbins and Judge, 2012). The realization of a conducive situation when employees and organizations have the same synergy in the orientation of achieving goals, striving to achieve the specified targets is a necessity when an employee sides with the organization. High organizational commitment owned by employees can make employees work with enthusiasm and enthusiasm to realize the achievement of organizational goals. High commitment of employees to the organization can create high organizational citizenship behavior of employees towards the organization. It can be concluded that organizational commitment influences organizational citizenship behavior.

2. Effect of Organizational Commitment on Employee Performance

From the results of the SPSS output as shown in Table 1, the calculated value of the $t$ value of variable $X$ to $Z$ is 7.176 , with a significance level of 0.000 , because the significance level is more than $0.05(0.000<0.05)$, it can be concluded that the organizational commitment affects employee performance. Based on the explanation, H0 is rejected and $\mathrm{H} 1$ is accepted, which means that organizational commitment affects employee performance.

The results of this study support research conducted by Khan et al. (2010), Gabriela, Kolibačova. (2014) which states that organizational commitment influences 
employee performance. The realization of a conducive situation when employees and organizations have the same synergy in the orientation of achieving goals, striving to achieve the specified targets is a certainty when an employee sides with the organization. High organizational commitment owned by employees can make employees work with enthusiasm and enthusiasm to realize the achievement of organizational goals. High employee commitment to the organization can create high employee performance. It can be concluded that organizational commitment influences employee performance.

3. The Effect of OCB on Employee Performance

From the results of the SPSS output as shown in Table 1, the $t$ value of the calculated $Y$ variable value of $\mathrm{Z}$ is 8,158 , with a significance level of 0,000 , because the significance level is more than $0.05(0.000<0.05)$, it can be concluded that OCB influences the performance the employee. Based on these explanations, therefore $\mathrm{HO}$ is rejected and $\mathrm{H} 1$ is accepted, meaning OCB has an effect on employee performance.

The results of this study support research conducted by Chelagat et al, (2015), Basu et al, (2017), Al-Mahasneh (2015), Mallick et al, (2014), Khazaei et al, (2011) which states that organizational Citizenship behavior influences employee performance.

Employees who have a high OCB level generally want the organization where they work can develop better, employees take various efforts so that the goals can be achieved together with the goals of the organization. Employees work without calculating profit and loss, even they can work outside the limits set by the organization or do work without being told to do so first. Employees with high OCB levels can work with enthusiasm, high morale so they can get the job done well and in accordance with organizational targets. It can be concluded that organizational citizenship behavior influences employee performance.

4. The Effect of Simultaneous Organizational Commitment and OCB on Employee Performance.

To answer the fourth hypothesis that organizational commitment and OCB affect the performance of lecturers simultaneously can be seen from Table 2 below.

Table 2. Simultaneous F test results

\begin{tabular}{lllllll}
\hline & \multicolumn{9}{c}{ ANOVAa } \\
\hline & Model & $\begin{array}{c}\text { Sum of } \\
\text { Squares }\end{array}$ & Df & Mean Square & F & Sig. \\
\hline & Regression & 10494,235 & 2 & 5247,117 & 282,861 &, $000 \mathrm{~b}$ \\
1 & Residual & 3858,438 & 208 & 18,550 & & \\
& Total & 14352,673 & 210 & & & \\
\hline
\end{tabular}

a. Dependent Variable: Z_Performance

b. Predictors: (Constant), Y_OCB, X_Organizational_Com

Sumber: Output SPSS 21.0 for windows

From the Anova test or the F test as shown in Table 2, the Fcount value of 282,861 is obtained with a probability level of $p$-value of 0,000 , because the significance level is far more than $0.05(0,000<0.05)$, it can be concluded that the organizational commitment variable and OCB together significantly influence employee performance variables. Based on this explanation, $\mathrm{H} 0$ is rejected and $\mathrm{H} 1$ is accepted, which means that 
this proves that organizational commitment and OCB variables together significantly influence employee performance variables. Thus the fourth hypothesis is accepted.

Meanwhile, to see how much the contribution of organizational commitment (X) and OCB (Y) to employee performance (Z) can be seen from the coefficient of determination $\mathrm{R} 2$ as shown in Table 3 below:

Table 3. Model Summary

Model Summary

\begin{tabular}{lllcc}
\hline Model & R & R Square & $\begin{array}{c}\text { Adjusted R } \\
\text { Square }\end{array}$ & $\begin{array}{c}\text { Std. Error of the } \\
\text { Estimate }\end{array}$ \\
\hline 1 &, $855 \mathrm{a}$ &, 731 &, 729 & 4,307 \\
\hline
\end{tabular}

a. Predictors: (Constant), Y_OCB, X_Organizational_Com

$\mathrm{R}$ value of 0.855 shows a double correlation (organizational commitment and $\mathrm{OCB}$ ) with employee performance. By considering variations in the value of $\mathrm{R}$ Square of 0.731 which shows the amount of contribution or contribution of organizational commitment variables and OCB is able to explain the employee performance variable of 73.1 percent and the remaining 26.9 percent is influenced by other factors not revealed in this model.

5. The Effect of Organizational Commitment Through OCB On Employee Performance.

To find out whether the OCB variable is able to mediate the variable organizational commitment to employee performance, the steps are as follows.

The direct influence of organizational commitment on employee performance

$$
\begin{aligned}
& =\text { Pyx }(\mathrm{p} 1) \\
& =0,480
\end{aligned}
$$

The indirect effect of organizational commitment on employee performance

$$
\begin{aligned}
& =\text { Pyx }(\mathrm{p} 2) \times \text { Pzy }(\mathrm{p} 3) \\
& =0,792 \times 0,480=0,38016
\end{aligned}
$$

Total influence (organizational commitment to employee performance)

$$
\begin{aligned}
& =\mathrm{p} 1+(\mathrm{p} 2 \times \mathrm{p} 3) \\
& =0,480+0,38016=0,86016 .
\end{aligned}
$$

The results of the path analysis show that organizational commitment can directly influence employee performance and can also indirectly affect organizational commitment to OCB (as an intervening variable) and then to employee performance. To determine the effect of mediation shown by the multiplication coefficient (p2 x p3) of 0.38016 significant or not, tested with the Sobel test as follows:

Calculate the standard error of the indirect effect coefficient (Sp2p3)

$$
\begin{aligned}
& S p 2 p 3=\sqrt{p 3^{2} S p 2^{2}+p 2^{2} S p 3^{2}+S p 2^{2} S p 3^{2}} \\
& S p 2 p 3=\sqrt{(0,480)^{2}(0,057)^{2}+(0,792)^{2}(0,050)^{2}+(0,057)^{2}(0,050)^{2}} \\
& S p 2 p 3=\sqrt{(0,2304.0,003249)+(0,627264.0,0025)+(0,003249.0,0025)} \\
& S p 2 p 3=\sqrt{0,0007485696+0,00156816+0,0000081225} \\
& S p 2 p 3=\sqrt{0,0023248521}=0,048
\end{aligned}
$$


Based on the results of $\mathrm{Sp} 2 \mathrm{p} 3$, we can calculate the value of $\mathrm{t}$ mediation effect statistics with the following formula:

$$
\mathrm{t}=\frac{p 2 p 3}{S p 2 p 3}=\frac{0,38016}{0,048}=7,920
$$

Because the value of tcount $=7.920$ is greater than the value of $t$ table with a significance level of $0.05,1.96$, it can be concluded that the mediation coefficient is 0.38016 , which means that there is a mediating effect.

\section{CONCLUSION AND SUGGESTION}

\section{Conclusion}

Based on the results of research and discussion in this thesis, it can be concluded as follows:

1. There is an influence of organizational commitment to organizational citizenship behavior of SPMI employees of private universities in West Sumatra. Where the most dominant dimension of organizational commitment influences organizational citizenship behavior is the dimension of normative commitment as measured by indicators of loyalty. This indicates that normative commitment as measured by high employee loyalty to the organization is very important and needed in improving organizational citizenship behavior of Internal Quality Assurance Unit employees of private universities in West Sumatra.

2. There is an influence of organizational commitment to the performance of employees of Internal Quality Assurance Unit Private University in West Sumatra. Where the most dominant dimensions of organizational commitment affect employee performance is the normative commitment dimension measured by loyalty indicators. This indicates that normative commitment as measured by high employee loyalty to the organization is very important and necessary in improving the performance of SPMI employees of private universities in West Sumatra.

3. There is an influence of organizational citizenship behavior on the performance of employees of Internal Quality Assurance Unit Private University in West Sumatra. Where the dimensions of organizational citizenship behavior that predominantly affect employee performance is the dimension of conscientiousness as measured by indicators of job completion. This indicates that conscientiousness as measured by being able to complete work ahead of schedule or above standards is very important and necessary in improving the performance of SPMI employees of private universities in West Sumatra.

4. There is an influence of organizational commitment and organizational citizenship behavior on the performance of Internal Quality Assurance Unit Private Universities in West Sumatra simultaneously.

5. Organizational citizenship behavior is able to mediate organizational commitment to the performance of employees of Internal Quality Assurance Unit Private University in West Sumatra. 


\section{Sugestion}

Based on the results of the conclusions and discussion beforehand in improving the performance of employees of Internal Quality Assurance Unit Private University in West Sumatra can be submitted suggestions that might be useful as follows:

1. In an effort to remind the performance of SPMI employees of private universities in West Sumatra, management needs to improve OCB with the dimension of Conscientiousness and indicators of completing work ahead of schedule and still improve other latent variables namely Perceived Organizational Support, commitment and competence that affect employee performance.

2. It is recommended for other researchers who want to conduct research with similar themes to add some variables that can influence organizational citizenship behavior and employee performance, such as organizational culture, organizational climate and career development, and for other researchers to expand the object of research not only limited to Private Universities in West Sumatra but can be done at other universities with broader regional coverage.

\section{REFERENCE}

Allameh, Sayyed M., Amiri, Samane dan Asadi, Ali. (2011). A Survey of Relationship between Organizational Commitments and Organizational Citizenship Behavior Case Study: Regional Water Organization of Mazandaran Province. Interdisciplinary Journal of Contemporary Research In Business. Vol 3, No 5.

Al-Mahasneh, M.A. (2015). The impact of Organizational Citizenship Behavior on Job Performance at Greater Amman Municipality. European Journal of Business and Management. Vol.7, No.36, 108-118.

Basu, Eeman, Pradhan, R.K., dan Tewari, H.R. (2017). Impact of Organizational Citizenship Behavior on Job Performance in Indian Healthcare Industries: The Mediating Role of Social Capital. International Journal of Productivity and Performance Management, Vol. 66 Issue: 6.

Chelagat, Lelei J., Chepkwony, Kiprop, P., Kemboi, A., (2015). Effect of Organizational Citizenship Behavior on Employee Performance in Banking Sector, Nairobi County, Kenya. International Journal of Business, Humanities and Technology. Vol. 5, No. 4.

Colquitt, Jason A., Jweffery A. LePine, ande Michael J. Wesson, (2011), Organizational Behavior, McGraw-Hill, New York.

Gabriela, Kolibačova. (2014). The Relationship Between Competency and Performance. Acta Universitatis Agriculturae et Silviculturae Mendelianae Brunensis, 62(6): 1315-1327.

Ghozali, I. (2012). Aplikasi Analisis Multivariate Dengan Program SPSS. Semarang: Penerbit Undip.

Gibson, James L., Donnelly Jr, James H., Ivancevich, John M., Konopaske, Robert (2012). Organizationa Behavior, Structure, Processes, Fourteenth Edition (International Edition). Avenue of The Americas, New York, NY 10020: McGraw-Hill.

Holsblat, Rachel. (2014). The Relationship between Commitment to the Organization, Perceived Organizational Support, Job Satisfaction, and Organizational Citizenship 
Behavior of Teachers. American Journal of Educational Research, 2014, Vol. 2, No. $12,1175-1181$.

Jex, S.M. (2002). Organizational Psychology: A Scientist-Practitioner Approach, John Wiley \& Sons Inc., New York, NY.

Khan et al, (2010)

Khazaei, K., Khalkhali, A. and Eslami, N. (2011). Relationship Between Organizational Citizenship Behavior and Performance of School Teachers in West of Mazandaran Province. World Applied Sciences Journal 13 (2): 324-330.

Kumar, K., Arti B., Ekta R. (2009). Linking the Big Five Personality Domains to Organizational Citizenship Behavior. International Journal of Psychological Studies, $1(2): 73-81$.

Mallick, E., Rabindra K.P., Hare R.T., dan Lalatendu K.J. (2014). Organizational Citizenship Behaviour, Job Performance and HR Practices: A Relational Perspective. Management and Labour Studies. 39(4) 449-460.

Mangkunegara A.P. (2011), Manajemen Sumber Daya Manusia Perusahaan. Bandung: PT. Remaja Rosdakarya.

Mathis, Robert L \& John H. Jackson. (2011). Manajemen Sumber Daya Manusia, edisi 9. Jakarta: Penerbit Salemba Empat.

Ortiz, M.Z., Rosario, E., Marquez, E., Gruñeiro, P.C. (2015). Relationship Between Organizational Commitments and Organizational Citizenship Behaviour in a Sample of Private Banking Employees. International Journal of Sociology and Social Policy, Vol. 35 Issue: 1/2, pp.91-106.

Podsakoff, M., Scott, B.M., Paine, J.B., Bachrach, D.G. (2000). Organizational Citizenship Behavior: Acritical Reviewof The Theoritical And Empirical Literature And Suggsestion For Future Research. Journal Of Management. 26/3. p.513-563.

Robbins, P. Stephen dan Timothy A., Judge, (2012), Perilaku Organisasi, Organizational Behaviour. Jakarta: Salemba Empat.

Rogelberg, S.G. (2007). Encyclopedia of Industrial and Organizational Psychology. California : Sage Publications.

Saxena S., dan Saxena R. (2015) Impact of Job Involvement and Organizational Commitment on Organizational Citizenship Behavior. International Journal Management Business. Res., 5 (1), 19-30.

Shweta, J., dan Srirang, J. (2010). Determinants of Organizational Citizenship Behavior: A Review of Literature. Journal of Management and Public Policy. 1 (2), pp. 27-36.

Sinambela, Lijan Poltak. (2016). Manajemen Sumber Daya Manusia Membangun Tim Kerja yang Solid untuk Meningkatkan Kinerja. Jakarta: Bumi Aksara.

Sopiah. (2008). Perilaku Organisasional dan Operasional Managemen. Yogyakarta: Andi Offset.

Wibowo (2016). Manajemen Kinerja. Edisi Kelima. Jakarta: PT. Raja Grafindo Persadara.

Wirawan. (2009). Evaluasi Kinerja Sumberdaya Manusia, Teori Aplikasi dan Penelitian. Jakarta: Salemba Empat. 